\title{
KEY FACTORS FOR IMPROVING TECHNICAL EFFICIENCY OF UPLAND RICE PRODUCTION
}

\author{
${ }^{1}$ Thanaporn Athipanyakul, ${ }^{1}$ Panusak Jitsaeng, ${ }^{2}$ Napa Pongkapan and ${ }^{1}$ Piansak Pakdee \\ ${ }^{1}$ Department of Agricultural Economics, Faculty of Agriculture, \\ ${ }^{2}$ Faculty of Management Science, \\ Khon Kaen University, Khon Kaen 40002, Thailand
}

Received 2013-11-16; Revised 2013-12-03; Accepted 2013-12-24

\begin{abstract}
Food security problems are major issues in developing countries, especially under the conditions of restricted farm resources and environmental degradation. The re-allocation of existing farm resources in the upland in order to reach a production of maximum output under given technologies and the estimated value of the technical efficiency have been important information for this purpose. The objective of this study, therefore, was to measure the technical efficiency of upland rice production in Thailand. The identification of key factors to improve the technical efficiency was additionally carried out. A stochastic frontier approach with the Cobb-Douglas production function was applied. Data used in this study has been drawn from 181 farmers. The findings showed that on average the technical efficiency was 0.70 and the rank of its value varied from 0.22 to 0.94 . A significant factor affecting the technical efficiency has been support in terms of transforming knowledge through a training program on upland rice production. Farmers, who grew upland rice for both household consumption and for commercial purposes, had a better performance than those who grew upland rice only for home consumption.
\end{abstract}

Keywords: Food Security, Efficiency, Stochastic Frontier, Translog Production

\section{INTRODUCTION}

Thailand is a major exporter of agricultural and food products to the world (Isavilanonda, 2011). Important crops are rice, sugarcane, cassava, para rubber trees and maize. More than one-half of land utilization in Thailand is covered by areas for rice cultivation (OAE, 2012). However, the trend shows that the production area of rice is declining and the production of field crops and perennial crops is increasing as a result of higher net returns as compared to rice (Isavilanonda, 2011). Kawasaki (2010) pointed out that in order to complement their production of rice, farmers have changed to the mono-cropping of field crops, such as sugarcane and cassava, which is often found in the northeast of Thailand (Athipanyakul, 2013). Therefore, the source of farm incomes relies only on those crops.
Under this production system, land degradation and food security problems have been reported. For example, Athipanyakul and Pakdee (2011) pointed out that more than fifty percent of the incomes of farm households in Khon Kaen Province, a region in which there are significant areas of sugarcane and cassava production, has been used to purchase food items including rice. Therefore, farmers cannot pay back loans to the lenders. The Thai government has promoted the practice of growing upland rice to small scale farmers as a crop rotation after the field crops have been harvested. Under this project, the process of plowing under rice straw after rice harvesting has also been taken into consideration. Not only does this practice to help improve soil fertility, but it also helps to reduce white leaf diseases that occur in sugarcane fields (Hamaharn, 2011). The pilot area of this project was in Khon Kaen Province, which is a Corresponding Author: Thanaporn Athipanyakul, Department of Agricultural Economics, Faculty of Agriculture, Khon Kaen University, Khon Kaen 40002, Thailand 
major area for field crop production such as sugarcane and cassava (OAE, 2012). The major objectives of this program are to promote farmers to produce upland rice for home consumption and to cut the cycle of white leaf disease in field crops, especially in sugarcane production. The upland rice, which is produced, but is not used for household consumption, can be sold to a market. However, farmers are rarely concerned about its production efficiency. Athipanyakul and Pakdee (2011) pointed out that farmers, who grow upland rice without using good production practices, often abandon their rice crops after planting. Athipanyakul (2013) claims that the average yield was only $300.66 \mathrm{~kg}$ per rai or 1.9 ton per hectare, however, the yield should be around $545 \mathrm{~kg}$ per rai or 3.4 ton per hectare (Konghakote, 2009).

The conditions of resource scarcity, food security and soil degradation have lead to examining how existing farm resources could be allocated to increase productivity of upland rice production without changing production technologies. The measurement of technical efficiency of upland rice production gives significant information to farmers and policy makers on how to improve upland rice production management in order to achieve maximum output under resource constraints. This study aims to measure the technical efficiency of upland rice production in Northeastern Thailand and to identify factors that affect the region's technical efficiency.

\section{MATERIALS AND METHODS}

\subsection{Data Collection}

The selection of the study area for this study used two criteria: (1) the area where upland rice production program was first introduced and (2) the area where almost all farmers have grown upland rice as a rotated crop in field crop production systems. According to these criteria, Ban Haed sub-district, located in Ban Haed district, Khon Kaen Province, in the northeastern region of Thailand where the program in which of upland rice production was first promoted as a rotated crop in sugarcane production in sugarcane production system, was selected as the study area. In this area, sugarcane is a major source of income for small scale farmers. The sugarcane production system in this area is mono-cropping. Farmers, who have paddy land, will grow rice for household consumption. However, farmers, who either lack enough land for such purposes or have land that is prone to flooding, have to use their income from sugarcane to buy rice. This pattern has led to food security problem. As this result, the upland rice production program was introduced by the government in 2011. To date, it seems that the adoption rate is high. Unfortunately, there is no research on this topic. Only Athipanyakul (2013) has indicated that farmers who grow upland rice as rotated crop often abandon their rice fields after planting, which may affect the technical inefficiency of upland rice production. Therefore, this study has taken this opportunity to select this area as a case study in order to measure the technical efficiency of upland rice production among farmers. A random sampling technique and a structured questionnaire were used to collect information from 182 farmers. However, one sample was discarded due to an outlier problem.

\subsection{Model Specification}

The technical efficiency of upland rice production refers to the ability of an individual farmer to reach the production frontier. The level of a farmer's Technical Efficiency (TE) can be measured by determining the gap between observed yields and the estimation of an ideal referred to as the production frontier (Farrell, 1957). The model that is generally used to measure the TE was firstly proposed by Aigner et al. (1977). It was named as the Stochastic Frontier Model (SFM). A general formula of SFM was applied to estimate the technical efficiency of upland rice producers in Khon Kaen province as shown in Equation (1):

$y_{i}=\int\left(X_{i} ; \beta\right) \exp \left(e_{i}\right) ; e_{i}=v_{i}-u_{i}$

Where:

$\mathrm{y}=$ Output of upland rice

$\mathrm{x}_{\mathrm{i}}=$ Factors determining upland rice output

$\beta_{\mathrm{i}}=$ Estimated parameters

The error term $\left(\varepsilon_{\mathrm{i}}\right)$ contains two components, $\mathrm{v}_{\mathrm{i}}$ and $\mathrm{u}_{\mathrm{i}}$. The first term is used to capture random anomalies in the upland rice production process, which are due to uncontrolled factors such as weather or governmental policies. It is assumed to be an independent and identically distributed (iid.) normal random variable with a zero mean and a variance $\sigma^{2}\left(v_{i} \sim\right.$ iid $\left.N\left(0, \sigma^{2}\right)\right)$. The last term takes into consideration the technical inefficiency in the production process of upland rice. The assumption of $\mu_{\mathrm{i}} \sim$ iid $\mathrm{N}\left(0, \sigma^{2}\right)$ is used, except it has non-negative random variables and arises from the truncation at zero of the normal distribution with variance (Coelli, 2005). This is the so-called halfnormal model. Aigner et al. (1977) used the maximum likelihood to estimate this model in term of $\sigma^{2}=\sigma_{v}^{2}+\sigma_{u}^{2}$ and $\lambda^{2}=\sigma_{u}^{2} / \sigma_{v}^{2}$. The technical efficiency of each upland rice farmer can be expressed as Equation (2): 
$\mathrm{TE}_{\mathrm{i}}=\frac{\mathrm{y}_{\mathrm{i}}}{\mathrm{f}\left(\mathrm{x}_{\mathrm{i}} ; \beta\right) \exp \left(\mathrm{v}_{\mathrm{i}}\right)}=\exp \left(-\mathrm{u}_{\mathrm{i}}\right)$

Battese and Coelli (1995) suggested that factors affecting technical inefficiency should be identified simultaneously with the inefficiency model, because those determinants may directly affect values of technical inefficiency. Suppose, $\delta_{0}$ and $\delta_{\mathrm{n}}$ are parameters to be estimated $(\mathrm{n}=1, \ldots, \mathrm{m})$ and the independent variables $\left(\mathrm{z}_{\mathrm{i}}\right)$ are factors determining technical inefficiency of upland rice production of individual farmer i. $\varepsilon_{\mathrm{i}}$ is a random variable, defined by the truncation at zero of the normal distribution with finite variance $\left(\sigma_{\varepsilon}^{2}\right)$. The inefficiency model is represented as Equation (3). Based on this equation, a variable with negative value of coefficient represents a positive effect to a score of technical efficiency of upland rice farmers. The maximum likelihood estimation method has been used to estimate Equation (1 and 3) simultaneously:

$\mathrm{u}_{\mathrm{i}}=\delta_{0}+\sum_{\mathrm{n}=1}^{\mathrm{m}} \delta_{\mathrm{n}} \mathrm{z}_{\mathrm{i}}+\varepsilon_{\mathrm{i}}$

To select a formula of production function, Translog and Cobb-Douglas production functions have been developed and utilized in several previous papers (Krasachat, 2012). The technical efficiency value estimated by incorrect production function specification can be biased (Latruffe et al., 2004). Felipe and Adams (2005) suggested that Cobb-Douglas production function will properly work, if inputs used in a production model are measured as a quantity instead of as a value. To discover a suitable functional form, this study used the chi-square test to select either the Cobb-Douglas production or the Translog production function which is proper in the analysis of this study. Therefore, Equation (1) can be rewritten in terms of a log linear function of Cobb-Douglas production function and Translog production function as Equation (4 and 5). The inputs that explain observed output of upland rice production were as follows: (1) the total size of the land $\left(\mathrm{x}_{1}\right)$ (expressed in hectares) that were devoted to upland rice; (2) the total labor $\left(\mathrm{x}_{2}\right)$ (measured in hours) including hired labor and family labor; (3) the expenditures in fertilizer $\left(\mathrm{x}_{3}\right)$ calculated in Thai currency (THB) and (4) the expenditures of other inputs $\left(\mathrm{x}_{4}\right)$ :

$$
\begin{aligned}
\ln \text { yield }_{\mathrm{i}}= & \ln \mathrm{A}+\beta \ln _{\mathrm{x} 1}+\beta_{2} \ln \mathrm{x}_{2}+\beta_{3} \ln \mathrm{x}_{3} \\
& +\beta_{4} \ln \mathrm{x}_{4}+\mathrm{v}_{\mathrm{i}}-\mathrm{u}_{\mathrm{i}}
\end{aligned}
$$

$$
\begin{aligned}
& \ln \text { yield }_{\mathrm{i}}=\ln \mathrm{A}+\beta \ln \mathrm{x}_{\mathrm{x} 1}+\beta_{2} \ln \mathrm{x}_{2}+\beta_{3} \ln \mathrm{x}_{3} \\
& +\beta_{4} \ln \mathrm{x}_{4}+\frac{1}{2}\left[\beta_{11}\left(\ln \mathrm{x}_{1}\right)^{2}+\beta_{22}\left(\ln \mathrm{x}_{2}\right)^{2}\right. \\
& \left.+\beta_{33}\left(\ln \mathrm{x}_{3}\right)^{2}+\beta_{44}\left(\ln \mathrm{x}_{4}\right)^{2}\right]+\beta_{12} \ln \mathrm{x}_{1} \mathrm{x}_{2} \\
& +\beta_{13} \ln \mathrm{x}_{1} \mathrm{x}_{3}+\beta_{14} \ln \mathrm{x}_{1} \mathrm{x}_{4}+\beta_{23} \ln \mathrm{x}_{2} \mathrm{x}_{3} \\
& +\beta_{24} \ln \mathrm{x}_{2} \mathrm{x}_{4}+\beta_{34} \ln \mathrm{x}_{3} \mathrm{x}_{4}+\mathrm{v}_{\mathrm{i}}-\mathrm{u}_{\mathrm{i}}
\end{aligned}
$$

Factors, that may have reduced the value of technical inefficiency, were identified according to the previous study. The first factor, that was expected to explain a value of the technical inefficiency is participation in an upland rice program, was measured as a dummy variable. It was equal to 1 if farmer had participated in the program and had been educated by an extension agent on how to produce upland rice $\left(D_{1}\right)$ and if otherwise, the value was 0 . It has often been shown in several studies that participation in a training program could improve technical efficiency (Manevska-Tasevska, 2013). The second variable was a farmer's goal for upland rice production. It was hypothesized that when compared to the farmers who produced rice solely for their own consumption, the farmers whose goals were commercial production usually had better production. The farmers' goals for upland rice production could be divided into the following three categories: (1) farmers who grew rice only for home consumption, (2) farmers who produced rice both for home consumption and for commercial purposes and (3) those who produced solely for commercial purposes. Therefore, two dummy variables were identified. $\mathrm{D}_{2}$ was equal to 1 if farmers grew upland rice solely for home consumption and, if otherwise, it was equal to 0 . $\mathrm{D}_{3}$ was equal to 1 if the farmer's objective for growing upland rice was to grow for both home consumption and for commercial purposes. It was also hypothesized that use of hybrid seed $\left(\mathrm{D}_{4}\right)$ may have decreased the technical inefficiency. This variable was identified as 1 if the farmer had used hybrid seed and if otherwise, the value was identified as 0 .

\subsection{Summary Statistics of Variables Used in the Model}

Table 1 represents the summary statistics of variables used in the production function and the inefficiency model. The average size of the land that had been devoted to upland rice production was 1.48 hectare per farm household. The maximum and minimum values of the total land used for upland rice production were 4.8 and 0.24 hectares per farm household. 
Table 1. Summary statistics of variable used in production function and inefficiency model

\begin{tabular}{|c|c|c|c|c|c|}
\hline Variable & Unit/type of variable & Mean & S.D & Max & Min \\
\hline \multicolumn{6}{|l|}{ Production function } \\
\hline Total land $\left(\mathrm{x}_{1}\right)$ & Hectare & 1.48 & 0.780 & 4.80 & 0.24 \\
\hline Total labor $\left(\mathrm{x}_{2}\right)$ & Man-days & 47.37 & 26.650 & 146.00 & 7.00 \\
\hline Fertilizer $\left(\mathrm{x}_{3}\right)$, & \$US & 120.79 & 89.421 & 700.00 & 20.00 \\
\hline Other inputs $\left(\mathrm{x}_{4}\right)$ & \$US & 328.95 & 200.230 & 973.33 & 60.00 \\
\hline \multicolumn{6}{|l|}{ Inefficiency model } \\
\hline Training program $\left(\mathrm{D}_{1}\right)$ & & 0.43 & 0.500 & 1.00 & 0.00 \\
\hline Growing upland rice for household consumption $\left(\mathrm{D}_{2}\right)$ & Dummy & 0.25 & 0.440 & 1.00 & 0.00 \\
\hline $\begin{array}{l}\text { Growing upland rice for household } \\
\text { consumption and for selling }\left(\mathrm{D}_{3}\right)\end{array}$ & Dummy & 0.62 & 0.490 & 1.00 & 0.00 \\
\hline Farmer uses hybrid seed $\left(D_{4}\right)$ & Dummy & 0.12 & 0.330 & 1.00 & 0.00 \\
\hline Household labor ratio to total labor $\left(\mathrm{Z}_{1}\right)$ & Ratio & 0.59 & 0.310 & 1.00 & 0.20 \\
\hline
\end{tabular}

Note: Each input is represented as the total instead of the average

Source: Own presentation (2013)

On average, the labor that had been used in upland rice production management was a total of 47.37 man-days ranging from 146 to 7 man-days. These figures included household laborers and hired laborers. The ratio of household labor to total labor was, on average, about 0.59 with a range of $0.20-1$, which suggests that some farmers had spent less time in upland rice production management. This may have negatively affected technical inefficiency. Total expenditures in fertilizer and other inputs averaged between 120.79 and 328.95 US dollars.

\section{RESULTS}

\subsection{Maximum Likelihood Estimates of Frontier Production Function}

This study used STATA 10.1 to carry out the Stochastic Frontier Production function and the Inefficiency Model. A likelihood ratio test was applied for selecting between Cobb-Douglas and Translog production functions. A value of log likelihood of the Cobb-Douglas Production function was -57.79 , while it was -51.94 for the Translog Production function (Table 2). A null hypothesis of this test was whether the second order and the interaction term in Translog Production functional form was equal to $0\left(\mathrm{H}_{0}: \beta_{\mathrm{jk}}=0 ; \mathrm{j} \leq \mathrm{k}=\right.$ $1,2,3,4)$. The findings showed that a statistical value of likelihood ratio was 1.57 and accepted the null hypothesis. Therefore the Cobb-Douglas Production Function was appropriate to capture the technical efficiency of upland rice production of farmers in Thailand. The explanation about technical inefficiency of the effects of upland rice production function was carried out by using this model. Additionally, testing the null hypothesis of no technical inefficiency in upland rice production model $\left(\mathrm{H}_{0}: \mu_{\mathrm{i}}=0\right)$ was carried out to counter the hypothesis that there is technical inefficiency in the model $\left(\mathrm{H}_{\mathrm{a}}: \mathrm{u}_{\mathrm{i}}>0\right)$. If null hypothesis is accepted, implying that an ordinary least square approach was more proper than the stochastic frontier approach. In this study, results showed that the statistical value of lambda was 4.42 , implying that there was a technical inefficiency effect in the upland rice production process at a level of $1 \%$ significance. Therefore, the stochastic frontier approach was adequate to represent of the data in this study (Table 2).

\subsection{Determinants of Technical Efficiency and its Scores}

The findings of this study reported that "training programs on upland rice $\left(\mathrm{D}_{1}\right)$ " and "growing upland rice for household consumption and for selling $\left(\mathrm{D}_{3}\right)$ " usually had better performance when compared to the farmers who produced rice solely for their household consumption. They may have tried to improve their production management in order to gain high yield and gain more income. Farmers, who participated in a training program, were able to benefit from the transfer of knowledge from an extension agent. Their knowledge can be improved (Krasuaythong, 2008) and they can overcome productivity constraints and improve the productivity (Rivera and Alex, 2008). Farmers, who used new varieties of seed, seemed to have a positive effect on the technical efficiency of upland rice production, even if it was insignificant. Tubtong and Napasintuwong (2010) claimed that farmers who grew conventional varieties of glutinous rice had higher levels of technical efficiency than those who grew new varieties of glutinous rice. However, there is an opportunity to improve the productivity of the new glutinous rice by having farmers learn how to allocate their farm resource endowment in order to improve a level of the technical efficiency (Table 2). 
Table 2. The estimation of stochastic frontier production and inefficiency model

\begin{tabular}{|c|c|c|c|c|}
\hline \multirow[b]{2}{*}{ Variable } & \multicolumn{2}{|c|}{ Cobb-Douglas } & \multicolumn{2}{|l|}{ Translog } \\
\hline & Coefficient & Standard error & Coefficient & Standard error \\
\hline \multicolumn{5}{|l|}{ Stochatic frontier production function } \\
\hline Constant & $0.424 * *$ & 0.051 & $0.369 * *$ & 0.098 \\
\hline Total land ( $\left(\mathrm{n}_{1}\right)$ & $0.188 * *$ & 0.074 & $0.201 * *$ & 0.067 \\
\hline Total labor $\left(\mathrm{In} \mathrm{x}_{2}\right)$ & $0.300 * *$ & 0.041 & $0.330 * *$ & 0.046 \\
\hline Fertilizer $\left(\operatorname{In} x_{3}\right)$ & -0.007 & 0.005 & -0.011 & 0.022 \\
\hline Other inputs $\left(\operatorname{In} x_{4}\right)$ & $0.363 * *$ & 0.051 & $0.351 * *$ & 0.055 \\
\hline Total land $*$ Total land $\left(\ln x_{1}^{2}\right)$ & & & -0.481 & 0.310 \\
\hline Total labor $*$ Total labor $\left(\ln \mathrm{x}_{2}^{2}\right)$ & & & 0.157 & 0.139 \\
\hline Fertilizer $*$ Fertilizer $\left(\ln x_{3}^{2}\right)$ & & & 0.001 & 0.008 \\
\hline Other inputs*Other inputs $\left(\ln \mathrm{x}_{4}^{2}\right)$ & & & 0.099 & 0.191 \\
\hline Total land $*$ Total labor $\left(\operatorname{In} \mathrm{x}_{1} *\right.$ In $\left.\mathrm{x}_{2}\right)$ & & & 0.280 & 0.165 \\
\hline Total land* Fertilizer $\left(\operatorname{In} \mathrm{x}_{1} * \operatorname{In} \mathrm{x}_{3}\right)$ & & & 0.013 & 0.015 \\
\hline Total land* Other inputs $\left(\operatorname{In} \mathrm{x}_{1} * \operatorname{In} \mathrm{x}_{4}\right)$ & & & 0.055 & 0.214 \\
\hline Total labor* Fertilizer $\left(\operatorname{In} \mathrm{x}_{1} * \operatorname{In} \mathrm{x}_{3}\right)$ & & & 0.005 & 0.010 \\
\hline Total labor* Other inputs $\left(\operatorname{In} \mathrm{x}_{2} *\right.$ In $\left.\mathrm{x}_{4}\right)$ & & & -0.113 & 0.104 \\
\hline Fertilizer* Other inputs $\left(\operatorname{In} \mathrm{x}_{3} * \operatorname{In} \mathrm{x}_{4}\right)$ & & & 0.000 & 0.011 \\
\hline \multicolumn{5}{|l|}{ Inefficiency model } \\
\hline Constant & -0.438 & 0.440 & -0.698 & 0.323 \\
\hline Training program on upland rice $\left(\mathrm{D}_{1}\right)$ & $-0.601 * *$ & 0.259 & $-0.602 * *$ & 0.264 \\
\hline Growing upland rice for household consumption $\left(\mathrm{D}_{2}\right)$ & -0.212 & 0.403 & -0.330 & 0.412 \\
\hline $\begin{array}{l}\text { Growing upland rice for household } \\
\text { consumption and for selling }\left(D_{3}\right)\end{array}$ & $-1.105 * *$ & 0.388 & $-1.159 * *$ & 0.402 \\
\hline Farmer uses hybrid seed $\left(\mathrm{D}_{4}\right)$ & -0.272 & 0.370 & -0.206 & 0.377 \\
\hline Household labor ratio to total labor $\left(\mathrm{Z}_{1}\right)$ & 0.201 & 0.425 & 0.396 & 0.422 \\
\hline Lambda $\left(\lambda^{2}=\sigma_{\mathrm{u}}^{2} / \sigma_{\mathrm{v}}^{2}\right)$ & $4.424 * *$ & 0.083 & $4.486 * *$ & 0.084 \\
\hline Log likelihood & -59.792 & & -51.942 & \\
\hline
\end{tabular}

$*$ and $* *$ represent significance at 5 and $1 \%$ level

Source: Own estimation (2013)

Table 3. Distribution of technical efficiency indices of upland rice farmers

\begin{tabular}{lrr}
\hline Technical efficiency score & Number of farmers & Percentage \\
\hline $0.0000-0.2000$ & 0.00 & 0.0 \\
$0.2001-0.4000$ & 14.00 & 7.7 \\
$0.4001-0.6000$ & 28.00 & 15.5 \\
$0.6001-0.8000$ & 78.00 & 43.1 \\
$0.8001-1.0000$ & 61.00 & 33.7 \\
Total & 181.00 & 100.0 \\
Mean & 0.70 & \\
Maximum & 0.94 & \\
Minimum & 0.22 & \\
\hline
\end{tabular}

Source: Own estimation (2013)

It was found that the average of technical efficiency for upland rice production is 0.70 or $70 \%$. This demonstrates that the farmers can increase the effectiveness of their technique in upland rice production by $30 \%$. The ranking of technical efficiency score of upland rice was from 22 to $94 \%$. This finding indicates that if the upland rice farmers with an average technical efficiency score could improve their production management process in order to become efficient upland rice farms, they could save a $25.53 \%$ of costs (i.e., 1-(0.70/0.94)) and could become the most efficient upland rice farms. On the other hand, those farmers having a minimal technical efficiency score would need a $76.60 \%$ (i.e., 1-(0.22/0.94)) cost savings to attain the level of the most efficient upland rice farms (Table 3). 


\section{DISCUSSION}

The estimated production function showed that all inputs used in the model that explained the output of upland rice were significantly positive, except for the fertilizers. The negative value found in estimating the production function is not an unknown phenomenon. A major and often referred to cause is an incorrect production function (Felipe and Asam, 2005). In this case, it seems that farmers have overused fertilizers, which has led to a decrease in its productivity. As shown in report by (OAE, 2011), from the 1970's through 2005 fertilizer consumption in Thailand sharply increased. Although the massive usage of fertilizers sharply increased, the yield of rice barely increased only 1 time.

The technical efficiency score of upland rice production in Thailand, that has been obtained from this study, was nearly equal to the technical efficiency score of modern rice varieties in Thailand as claimed by Srisompun and Isvilanonda (2012). The authors indicated that the average value of technical efficiency of those modern rice varieties in the crop year 2007/08 was 0.73 , which implies that there is room to improve the technical efficiency of rice production in Thailand. Several studies reported that Thai farmers had produced below maximum potential output (Songsrirod, 2007; Srisompun and Isvilanonda, 2012). It seems that the average technical efficiency of rice production in Thailand was lower than the technical efficiency of rice farmers in Vietnam (0.82) (Khai and Yabe, 2011) and in Nigeria (0.87) (Tijani, 2006). The improvement of the technical efficiency must be made in the farmer's characteristics, the characteristics of the farms, the environmental conditions and the agricultural practices (Huq and Arshad, 2010; Idris et al., 2013).

\section{CONCLUSION}

This study aims to apply the stochastic frontier analysis to measure the technical efficiency of upland rice farmers in Northeastern Thailand. An analysis of the factors enhancing the technical efficiency of upland rice production was carried out by using the stochastic frontier approach with the Cobb-Douglas production function. The average technical efficiency score was 0.698 and regarding the technical efficiency scores of the observed upland rice farmers there were big difference among them which were reported. This implies that an increase in upland rice output and decrease in costs could be possible by using given technologies. The technical efficiency scores of upland rice farmers were significantly affected by a training program and each farmer's goal for upland rice production. From these findings, a conclusion can be drawn that a farmer's knowledge can be improved by conducting a training program about upland rice and this can improve a farmer's performance. Additionally, the goal for the introduction of the upland rice production program should not only be concerns about food security, but should also be the production of minor crops from which farmers can gain income.

Due to some limitations of data available, variables use as factors determining a level of technical efficiencies in the study were limited. Some important variables such as human capital, socio-economic characteristics of farmers, production management skill of farmers should be taken into account in further research. Also, a statistical problem of selection biased that is often happen in the project evaluation should be taken into account in the efficiency model.

\section{ACKNOWLEDGEMENT}

The authors are grateful to all research assistants and to the upland rice farmers for their help and support. Last but not least, the special thank goes to the Thailand Research Fund (TRF).

\section{REFERENCES}

Aigner, D.J., C.A.K. Lovell and P. Schmidt, 1977. Formulation and estimation of stochastic frontier production function models. J. Econ., 6: 21-37. DOI: 10.1016/0304-4076(77)90052-5

Athipanyakul, T. and P. Pakdee, 2011. The marketing feasibility of upland rice in northeastern Thailand. KhonKaen University, KhonKaen Thailand.

Athipanyakul, T., 2013. Sustainability of Upland Rice Production and Marketing Management in Upper Northeastern, Thailand. Thailand Research Fund, Bangkok, Thailand.

Battese, G.E. and T.J. Coelli, 1995. A model for technical inefficiency effects in a stochastic frontier production function for panel data. Empirical Econ., 20: 325-332. DOI: 10.1007/BF01205442

Coelli, T., 2005. An Troduction to Efficiency and Productivity Analysis. 1st Edn., Springer, New York, ISBN-10: 0387242651, pp: 349.

Farrell, M.J., 1957. The measurement of productive efficiency. J. Royal Soc. Series A, 120: 253-290. 
Felipe, J. and F.G. Adams, 2005. "A theory of production" the estimation of the cobb-douglas function: A retrospective view. Eastern Econ. J., 31: 427-445.

Hamaharn, T., 2011. White Leave Disease: Office of the Cane and Sugar Board. Ministry of Industry, Bangkok, Thailand.

Huq, A.S.M.A. and F.M. Arshad, 2010. Technicla efficiency of chili production. Am. J. Applied Sci., 7: 185-190. DOI: 10.3844/ajassp.2010.185.190

Idris, N.D.M., C. Siwar and B. Talib, 2013. Determinants of technical efficiency of pineapple farming. Am. J. Applied Sci., 10: 426-432. DOI: 10.3844/ajassp.2013.426.432

Isavilanonda, S., 2011. Food Security in Thailand: Status, Rural Poor Vulnerability and Some Policy Options1. Department of Agricultural Economics, Faculty of Agriculture, Kasetsart University, Bangkok.

Kawasaki, J., 2010. Thailand's Rice Farmers Adapt to Climate Change.

Khai, H.V. and M. Yabe, 2011. Technical efficiency analysis of rice production in Vietnam. J. Int. Soc. Southeast Asian Agric. Sci., 17: 135-146.

Konghakote, P., 2009. Sew gliang alternative upland rice in undulating area of northeast Thailand. Proceedings of Rice and Temperate Cereal Crops Annual Conference, (RTCCAC' 09), Thailand, pp: 50-57.

Krasachat, W., 2012. Organic production practices and technical inefficiency of durian farms in Thailand. Proceedings of the International Conference Emerging Markets Queries in Finance and Business, Oct. 24-27, Petru Maior University of Tîrgu-Mures, Romania, pp: 445-450. DOI: $10.1016 / \mathrm{S} 2212-$ 5671(12)00178-5

Krasuaythong, T., 2008. Technologies Adoption in Vegetable Production in Northern Thailand. PhD. Dissertation, Institute of Development and Agricultural Economics. University of Hannover, Germany.
Latruffe, L., K. Balcombe, S. Davidova and K. Zawalinska, 2004. Determinants of technical efficiency of crop and livestock farms in Poland. Applied Econ., 36: 1255-1263. DOI: 10.1080/0003684042000176793

Manevska-Tasevska, G., 2013. Farmers' knowledge attributes contribute to attaining higher farm technical efficiency: A transition economy case. J. Agric. Educ. Extension, 19: 7-19. DOI: 10.1080/1389224X.2012.746001

OAE, 2011. Statistical data of fertilizer consumption. Office of Agricultural Economics, Thailand.

OAE, 2012. Statistical data of upland rice production. Khon Kaen: Agriculture Office of Khon Kaen, Thailand.

Rivera, W.M. and G.E. Alex, 2008. Human resource development for modernizing the agricultural workforce. Hum. Resou. Dev. Rev., 7: 374-386. DOI: $10.1177 / 1534484308324633$

Songsrirod, N., 2007. Technical efficiency and the determinants of technical inefficiency on conventional and certified organic jasmine rice farms in yasothon province. Doctor of Philosophy Thesis, Kasetsart University, Thailand.

Srisompun, O. and S. Lsvilanonda, 2012. Efficiency change in Thailand rice production: Evidence from panel data analysis. J. Dev. Agric. Econ., 4: 101108.

Tijani, A.A., 2006. Analysis of the technical efficiency of rice farms in Ijesha Land of Osun State, Nigeria. Agrekon: Agric. Econ. Res. Policy Practice Southern Africa, 45: 126-135. DOI: 10.1080/03031853.2006.9523738

Tubtong, K. and O. Napasintuwong, 2010. Technical efficiency of glutinous rice and traditional glutinous rice variety. Proceedings of the 11th Graduate Research Conference, (GRC' 10), Khon Kaen University, Khon Kaen, Thailand. 